\title{
Invertebrate distribution patterns and river typology for the implementation of the water framework directive in Martinique, French Lesser Antilles
}

\author{
C. Bernadet ${ }^{(1),(2),(3)}$, H. Touron-Poncet ${ }^{(1),(2),(3)}$, C. Desrosiers ${ }^{(1),(2),(3)}$, \\ A. Compin $^{(1),(2)}$, N. Bargier ${ }^{(3),(4)}$, R. Céréghino ${ }^{(1),(2) \star}$
}

Received September 21, 2012

Revised January 15, 2013

Accepted January 15, 2013

\begin{abstract}
Key-words: biological indicators, overseas regions, reference conditions, river classification, tropical rivers

Over the past decade, Europe's Water Framework Directive provided compelling reasons for developing tools for the biological assessment of freshwater ecosystem health in member States. Yet, the lack of published study for Europe's overseas regions reflects minimal knowledge of the distribution patterns of aquatic species in Community's outermost areas. Benthic invertebrates (84 taxa) and land-cover, physical habitat and water chemistry descriptors (26 variables) were recorded at fifty-one stations in Martinique, French Lesser Antilles. Canonical Correspondence Analysis and Ward's algorithm were used to bring out patterns in community structure in relation to environmental conditions, and variation partitioning was used to specify the influence of geomorphology and anthropogenic disturbance on invertebrate communities. Species richness decreased from headwater to lowland streams, and species composition changed from northern to southern areas. The proportion of variation explained by geomorphological variables was globally higher than that explained by anthropogenic variables. Geomorphology and land cover played key roles in delineating ecological sub-regions for the freshwater biota. Despite this and the small surface area of Martinique $\left(1080 \mathrm{~km}^{2}\right)$, invertebrate communities showed a clear spatial turnover in composition and biological traits (e.g., insects, crustaceans and molluscs) in relation to natural conditions.
\end{abstract}

\section{ABSTRACT}

RÉSUMÉ

Patrons de distribution des invertébrés et typologie des rivières pour la mise en œuvre de la Directive Cadre Européenne sur l'Eau en Martinique, Antilles Françaises

Mots-clés : indicateurs biologiques, outre-mer,
Au cours de la dernière décennie, la Directive Cadre Européenne sur l'Eau a promu le développement d'outils de bioindication de la qualité des eaux douces au sein des états membres. L'absence de travaux sur l'Outre-Mer révèle une connaissance minimale de la distribution des espèces aquatiques dans ces régions de l'Europe. Les invertébrés benthiques (84 taxons), ainsi que des variables décrivant l'utilisation des terres, I'habitat physique et la chimie de l'eau (26 variables) ont été

(1) Université de Toulouse, INP, UPS EcoLab (Laboratoire Ecologie Fonctionnelle et Environnement), 118 Route de Narbonne, 31062 Toulouse, France

(2) CNRS, EcoLab, 31062 Toulouse, France

(3) Asconit Consultants Caraïbes, ZI Champigny, 97224 Ducos, Martinique, France

(4) Asconit Consultants, Parc Scientifique Tony Garnier 6-8 espace Henry Vallée, 69366 Lyon Cedex 07, France

* Corresponding author: regis.cereghino@univ-tlse3.fr 
conditions de référence, classification, rivières tropicales quantifiés sur 51 stations en Martinique (Antilles Françaises). Des analyses canoniques et l'algorithme de Ward ont permis de dégager des patrons d'organisation des communautés en relation avec les conditions environnementales, puis une partition de variance a permis de préciser l'influence de la géomorphologie et des perturbations anthropiques sur ces patrons. La richesse spécifique décroît des cours d'eau de tête de bassin à la plaine, et la composition des communautés change du nord au sud de l'île. La proportion de variance expliquée par les variables géomorphologiques est globalement supérieure à celle expliquée par les variables anthropiques. La géomorphologie et la couverture végétale définissent les sous-régions écologiques pour la faune aquatique. Les îles des Caraïbes ont des pools d'espèces pauvres; pourtant, et malgré la petite surface de la Martinique $\left(1080 \mathrm{~km}^{2}\right)$, les communautés d'invertébrés montrent une variabilité spatiale en terme de composition et de traits (insectes, crustacés, mollusques) en relation avec les conditions locales.

\section{INTRODUCTION}

Intended to protect all surface waters in Member States, Europe's Water Framework Directive (WFD, 2000/60/EC) has provided compelling reasons for developing practical tools for the biological assessment of freshwater ecosystem health. According to the WFD guidelines, ecological health must be defined in terms of similarity to an undisturbed ("reference") state. The Reference Condition Approach (RCA, Bailey et al., 2003) notably implies the characterization of biological communities (fish, invertebrates, diatoms, phytoplankton, plants) expected to occur where there is (almost) no anthropogenic disturbance (Chaves et al., 2011; Wallin et al., 2003). Geomorphological, physical, and chemical attributes of freshwater systems have to be associated with biological features too when defining undisturbed conditions. Recent examples of RCA-based works in continental Europe can be found in Gabriels et al. (2010) (Belgium), Delgado et al. (2010) (Spain), Kelly et al. (2012) (Ireland), and Mondy et al. (2012) (France).

The European Union (EU) has 34 overseas territories which belong to six member states (Denmark, France, the Netherlands, Portugal, Spain, and the United Kingdom). Although they occur across a range of biogeographic areas from polar to tropical latitudes, these territories are subjected to EU's water legislation too. In other words, overseas regions have the same water policy objectives as the continental ones, and must fulfil WFD's goals. To date however, there has been no published WFD-compliant method for river bioassessment in any European overseas region, and even preliminary work (i.e., stream classifications based on river biota, identification of reference conditions) is lacking. Reference conditions and metrics designed for the European continent cannot be transposed to overseas regions, at least for two major reasons. Firstly, biogeographic differences in community composition/structure preclude the adaptation of current metrics. For instance, entire indicator groups are absent from some biogeographic areas, e.g., stoneflies (a particularly sensitive group of taxa in Europe) are absent in the Lesser Antilles (Caribbean Sea), Macaronesia (Atlantic Ocean) and the Reunion (Indian Ocean), and are scarce in French Guiana (South-America) (ENSAT, 1995; Hughes, 2005; Stark, 2000; Starmühlner, 1977). Secondly, and perhaps more importantly, limited scientific effort has been directed at characterizing how rivers in overseas Europe differ in terms of biological communities, and how these communities respond to changes in abiotic conditions. As a consequence, tolerance to water pollution and Ecological Quality Ratios (ratios between observed biological parameters and the expected values under reference conditions (Anonymous, 2003)) cannot be defined yet.

The present study takes a step towards the development of WFD-compliant bioassessment tools in overseas Europe. It was conducted in Martinique (French Lesser Antilles, Caribbean), one of France's eleven inhabited overseas territories. Martinique freshwaters suffer from chemical-physical degradation due to human population growth on a cramped territory (400 000 inhabitants in 2009, $1100 \mathrm{~km}^{2}$; INSEE, 2009). Routine surveys conducted 
by local consultancies and environmental agencies revealed changes in river invertebrate communities in relation to local physical and chemical conditions (Asconit Consultants, Unpublished data). However, we still don't know how geomorphological variables influence invertebrate distribution patterns in Carribean islands, and to what extent anthropogenic disturbance overrides geomorphological controls on the distribution patterns of macroinvertebrates at the local (station) to regional (island) scale (Huryn and Wallace, 1987 ; Sandin and Johnson, 2000; Wu and Legg, 2007). To address this question, we sampled invertebrate communities at 51 stations distributed across Martinique's stream systems, and we used an a posteriori inductive approach to bring out patterns of macroinvertebrate communities in relation to a set of physical, chemical and land-cover variables. Variance partitioning was used to tease out the effects of geomorphology (e.g., elevation, riverbed substrate) and anthropogenic impacts (land-cover, water chemistry). We discuss freshwater invertebrate diversity and distribution in the context of water policy and make suggestions for future directions.

\section{MATERIAL AND METHODS}

\section{$>$ STUDY AREA}

Martinique is a volcanic island of the French Lesser Antilles (surface area $=1080 \mathrm{~km}^{2}$ ). The North of the island is mountainous ("Montagne Pelée" volcano, elevation = $1397 \mathrm{~m}$ a.s.l.) and covered by wet forest, the South area consists in plains and hills (maximum elevation $=507 \mathrm{~m}$ a.s.I.) mainly covered by agricultural and urban lands (Fort-de-France capital city, tourist resorts). Running waters consist in 70 streams, mostly concentrated in the North area. Watersheds are $15 \mathrm{~km}^{2}$ on average (maximum area $=116 \mathrm{~km}^{2}$ ). The climate is tropical moist, the mean annual air temperature is $27^{\circ} \mathrm{C}$. Rainfalls range from $<1000 \mathrm{~mm}$ per year in the South to $>10000 \mathrm{~mm}$ per year on the northern mountaintops. A dry season ("Carême") occurs between December and April.

\section{> ENVIRONMENTAL VARIABLES}

Fifty-one stations were sampled during the dry season in April 2010 (Figure 1). These stations were evenly distributed and represented 45 rivers (the island has a total of 70 referenced rivers). All unimpacted (reference) stations belonged to the network of reference stations formally defined by the regional Environmental Administration (Direction de l'Environnement, de l'Aménagement et du Logement, Martinique) as per WFD rules. Stations subjected to anthropogenic impacts (urban, industrial or agricultural runoff, wastewater treatment plants) were selected based on field observation and on water chemistry analyses provided to us by the above-mentioned Administration.

Each station was characterized using fourteen chemical variables, nine physical variables and three land-cover variables. Three physical-chemical variables were directly measured in the field using a multiparametric Hydrolab Quanta probe: conductivity $\left(\mu \mathrm{S} \cdot \mathrm{cm}^{-1}\right), \mathrm{pH}$, and dissolved oxygen $\left(\mathrm{mg} \cdot \mathrm{L}^{-1}\right)$. Water samples were also collected at the same time of invertebrate sampling, transported to the laboratory on ice and frozen to be analyzed by the Laboratoire Départemental de la Drôme, France. The following chemical variables were measured following standard methods summarized in ASCONIT (2012): turbidity (NTU), suspended solids, ammonium, nitrate, sulfate, bicarbonate, chloride, silice, total phosphorus and potassium, and biological oxygen demand $\left(\mathrm{mg} \cdot \mathrm{L}^{-1}\right)$.

The percentage composition of substrate types was determined at each sampling station as: \%litter, \%submerged vegetation, \%submerged roots, \%sand (particle size $<2 \mathrm{~mm}$ ), \%gravels (2-25 mm), \%pebbles (25-250 mm), \%boulders ( $>250 \mathrm{~mm}$ ), and \%rocky outcrops. Together with elevation above sea level ( $m$ a.s.I.), these physical variables relate the location of sampling stations along the upstream-downstream river continuum. 


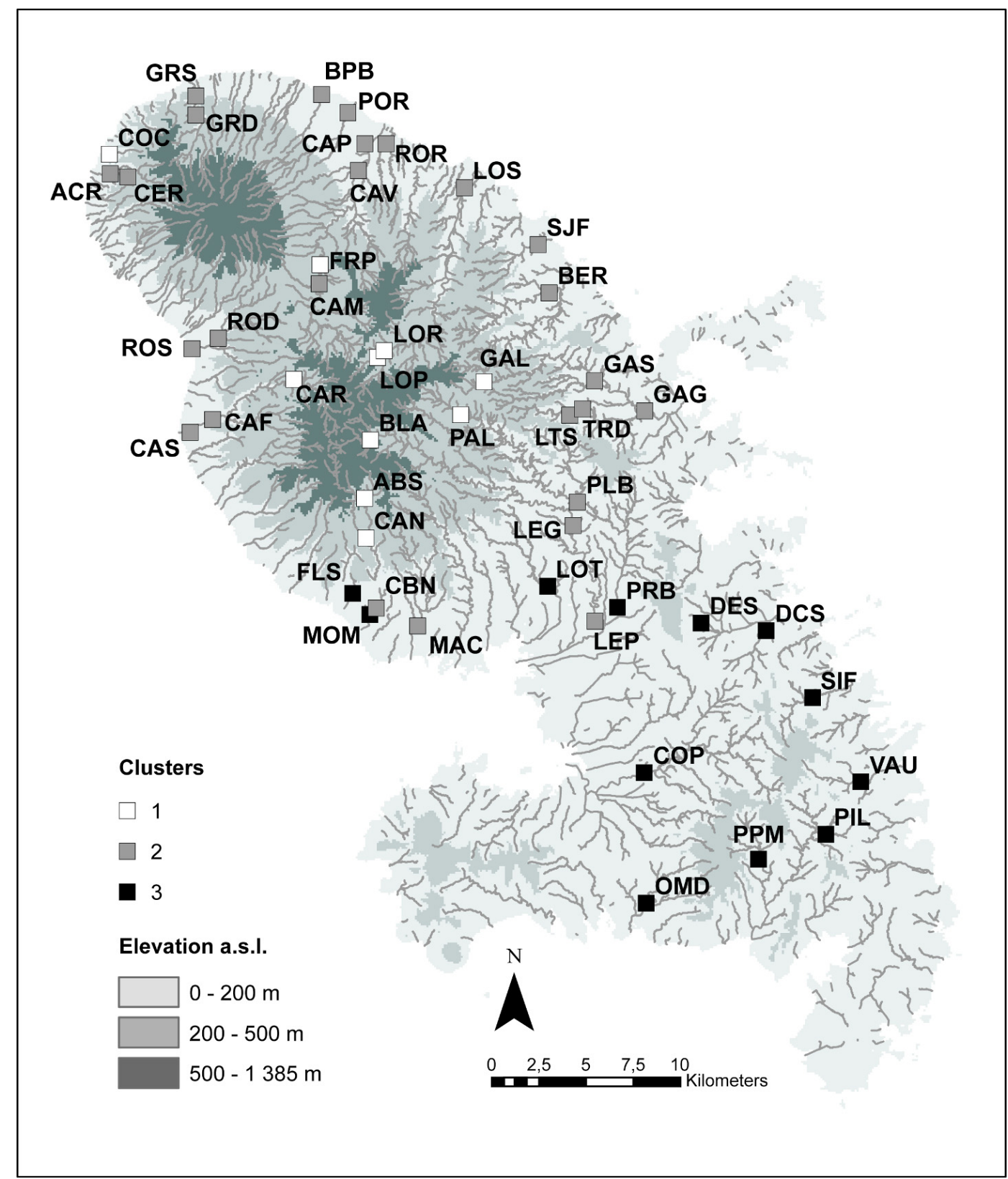

Figure 1

Distribution of sampling stations in the Martinique rivers. Different markers are used to assign stations to clusters 1-3 derived from the CCA analysis and Ward's algorithm (see also Figure 2).

Finally, land cover was quantified at each station using a Geographic Information System (GIS, ESRI ArcGis 10). The 3 land-cover variables extracted were the percent areas covered by forest (areas occupied by broad-leaved forest, shrubs and herbaceous vegetation associations), urbanization (industrial, commercial and transport units; artificial and non-agricultural vegetated areas), and agriculture (arable lands, permanent crops and pasture). These percentages were estimated on $1000 \mathrm{~m}$-long $\times 100 \mathrm{~m}$-large riparian corridor (buffer zone) located immediately upstream from the sampling station (see Compin and Céréghino (2007) for methodological and theoretical details). Digital land-cover information was extracted from the CORINE land-cover database for Martinique (French Ministry of Ecology, http://www.statistiques.developpement-durable. gouv.fr/donnees-ligne/t/telechargement-donnees-sig-corine-land-cover-dom.html; see also 
Cruiskshank and Tomlison (1996)). This database was generated from orthorectified satellites images and provides thematic GIS map layers including up to 24 land-cover classes with a mapping scale of 1:100 000 .

\section{>INVERTEBRATE SAMPLING}

Macroinvertebrate sampling was carried out during the dry season in April 2010, during low flow, using the Multi-Habitat Sampling normalized protocol (norm XP T 90-333 in AFNOR, 2009). Twelve sample units were taken from the various habitat types, according their coverage area. Sample units are distributed as follows: four sample units were taken from marginal habitats (i.e. habitats which cover less than $5 \%$ of the sampling station) (group A), four samples units were taken from major habitats (habitats which cover at least $5 \%$ of the sampling station) and potentially have a high carrying capacity for invertebrates (group B), and the last four sample units were taken from major habitats too but in proportion to their relative coverage within the sampling station (group C), taking into account those habitats already sampled in group B. All samples were taken with a standard Surber sampler (sampling area $0.05 \mathrm{~m}^{2}$, mesh size $500 \mu \mathrm{m}$ ), and preserved in formalin (4\% final concentration). In the laboratory, invertebrates were sorted, identified to species or genus (except for Oligochaeta and Diptera), and counted, in order to calculate the density of each taxon (individuals per $\mathrm{m}^{2}$ ).

\section{> DATA ANALYSIS}

Multivariate ordination was used to examine the relationships between 26 environmental variables, sampling stations, and density data for 84 invertebrate taxa. The densities were log $(n+1)$-transformed prior to analysis. An initial Detrended Correspondence Analysis (DCA) in CANOCO v4.5 (Ter Braak and Smilauer, 1998) showed high species turnover (gradient = 2.629) along Axis 1; thereafter, a Canonical Correspondence Analysis (CCA) was used to examine invertebrate relationships with sampling stations and with the environmental variables (Lepš and Šmilauer, 2003). Forward selection was employed to test which of the environmental variables explained a significant $(P<0.05)$ proportion of the species variance. The significance of explanatory variables was tested against 500 Monte-Carlo permutations. Ward's algorithm was applied to the scores of sampling stations on the CCA axes, in order to divide the scatterplot into clusters. To ease interpretations, these clusters were plotted on a geographic map of the island. The adequacy of invertebrate sampling was assessed by plotting the cumulative frequency of species against sampling effort (sample-rarefaction curve with 500 randomizations) for each cluster (Colwell et al., 2004).

In order to further specify the relative influence of geomorphological controls and anthropogenic disturbance on the general patterns of invertebrate community structure, variation partitioning was applied as follows: (1) partial CCA of the species matrix constrained by significant geomorphological variables (elevation, \%boulders, \%rocky outcrops, conductivity, see results) and significant "anthropogenic" variables as covariate (\%agricultural lands, suspended solids, dissolved oxygen, ammonium); (2) partial CCA of the species matrix constrained by significant anthropogenic variables and significant geomorphological variables as covariate, and (3) CCA of the species matrix constrained by a matrix of each group of variables one at a time. We estimated the pure effects of geomorphology and anthropogenic disturbance as the sum of eigenvalues of canonical axes in analyses (1) and (2), respectively. The effect shared by both groups of variables (shared variance fraction) was obtained by subtracting the sum of variability of (1) and (2) from the amount of variability explained by (3) (Lepš and Šmilauer, 2003). Variation partitioning was first applied to the entire dataset (51 sampling stations), and then to each cluster individually.

Finally, in order to provide further indication of invertebrate community responses, the distributions of species richness, community evenness (Simpson index) and entropy (Shannon index) were compared among Ward clusters using Kruskall-Wallis tests. These statistical tests were performed using the Past software (version 2.15). 

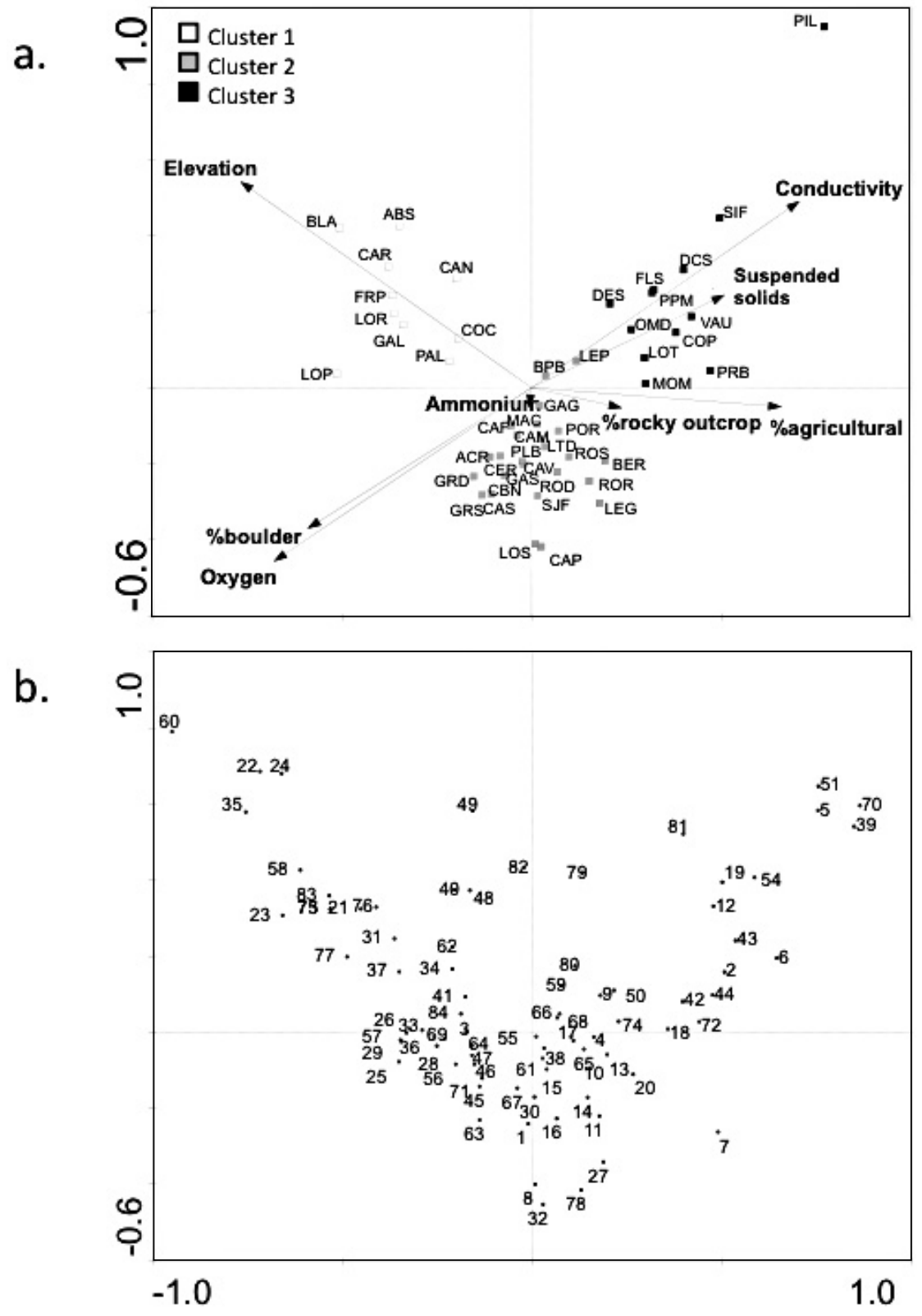

\section{Figure 2}

Canonical Correspondence Analysis (CCA) biplots. (a) Sampling stations and environmental variables. Environmental variables are represented as vectors; directions show the gradients, arrow length represents the strengths of the variables on the ordination space. In order to lighten the figure, only variables explaining a significant $(P<0.05)$ proportion of the species variance are represented. Different markers are used to assign stations to clusters 1-3 (see text for a description). (b) distribution of invertebrate taxa in ordination space. Invertebrates are identified by numbers as in Table I.

\section{RESULTS}

\section{> CLASSIFICATION OF SAMPLING STATIONS}

Axes 1 and 2 of the CCA accounted for $19.9 \%$ of the total species variance and $29.8 \%$ of the species-environment relationship. Eigenvalues for axes 1 and 2 were 0.31 and 0.22 , respectively. Species-environment correlations were 0.963 for axis 1 and 0.977 for axis 2 .

Forward selection and Monte-Carlo permutations allow us to identify eight variables as explaining a significant amount of the species variance (arrows in Figure 2a): elevation, 
\%agricultural lands and dissolved oxygen $(P=0.002)$, suspended solids and ammonium $(P=0.018)$, \%boulders and conductivity $(P=0.022)$, \% rocky outcrops $(0.024)$.

Ward's algorithm helped to identify three clusters of stations (Figure 2). When clusters were plotted on a geographic map (Figure 1), stations in clusters 1, 2 and 3 delineated three major sub-regions, i.e., northern area at high elevations, northern area at mid- to low-elevations, and southern area, respectively. Stations in cluster 1 were surrounded by dense forest, and overall, the area was deprived of permanent human presence. Based on our analyses and on field observations, most of these stations were supposedly unimpacted, reference stations. Conversely, stations in clusters 2 and 3 were located in agricultural or urban areas. Stations in cluster 2 were characterized by coarse rocky substrate and were well oxygenated, but showed high ammonium concentrations. Stations in cluster 3 were typical of rivers flowing through agricultural lands and showed high concentrations of suspended solids. Higher conductivity values in these areas are related to well-known geochemical anomalies due to the lithology (Lions et al. (2008); high concentrations of $\mathrm{Na}, \mathrm{Ca}, \mathrm{Mg}, \mathrm{Cl}$ ) rather than to anthropogenic impacts.

\section{> COMPOSITIONAL STRUCTURE OF INVERTEBRATE COMMUNITIES}

Eighty-four taxa were identified from 51 stations (Table I, Figure 2b). Based on asymptote values of rarefaction curves, we estimate that we sampled $93 \%, 98 \%$ and $100 \%$ of the estimated richness in clusters 1, 2, and 3, respectively. Invertebrate communities of stations in cluster 1 were mainly composed of insects ( $>90 \%$ of the taxa, Figure 3), especially Trichoptera (mostly Hydropsychidae), Ephemeroptera (Baetidae and Leptohyphidae) and Coleoptera (Elmidae). Stations in cluster 2 showed high density for insect orders/families (Trichoptera Philopotamidae and Hydroptilidae, and Diptera Chironomidae), but also had higher density for Mollusca (Thiaridae, Physidae) and Crustacea (Atyidae and Palaemonidae). Stations in cluster 3, which were located in southern part of the island, were characterized by high densities of Mollusca (Thiaridae, Planorbidae and Hydrobiidae), Crustacea (Atyidae and Palaemonidae), and Ephemeroptera (Baetidae and Caenidae). Trichoptera (Helicopsychidae, Hydroptilidae, philopotamidae and Hydroptilidae) and Coleoptera (Psephenidae) were also present, but remained scarce.

\section{> VARIATION PARTITIONING}

Among the eight significant explanatory variables previously identified by means of forward selection, four were associated to anthropogenic pressure (oxygen, ammonium and suspended solids, \%agricultural lands). The others (elevation, \%boulders, \%rocky outcrop and conductivity) were related to geomorphology sensu lato. The proportions of pure anthropogenic variation and pure geomorphological variation for the 51 stations were $20.0 \%$ and $28.7 \%$, respectively. The effect shared by both groups of variables was $11.6 \%$. Finally, the unexplained fraction of the overall variation in invertebrate communities was $39.7 \%$.

When variation partitioning applied to each cluster, the total explained variation was higher for clusters 1 and 3 than for the 51 sites (Table II; >87\% in clusters 1 and 3). The proportion of pure geomorphological variation $(56.6 \%)$ was higher than the proportion of pure anthropogenic variation (31.7\%) in cluster 1. However, proportions of pure geomorphological variation and pure anthropogenic variation were similar in cluster 2 (18.1 and $17.9 \%$, respectively) and in cluster 3 (43.2 and $41.1 \%$, respectively). Finally, it should be noted that cluster 2 showed the highest proportion of unexplained variance $(61.8 \%)$, suggesting that the most relevant determinants of invertebrate diversity for this specific subset of stations were not included in our analyses. 


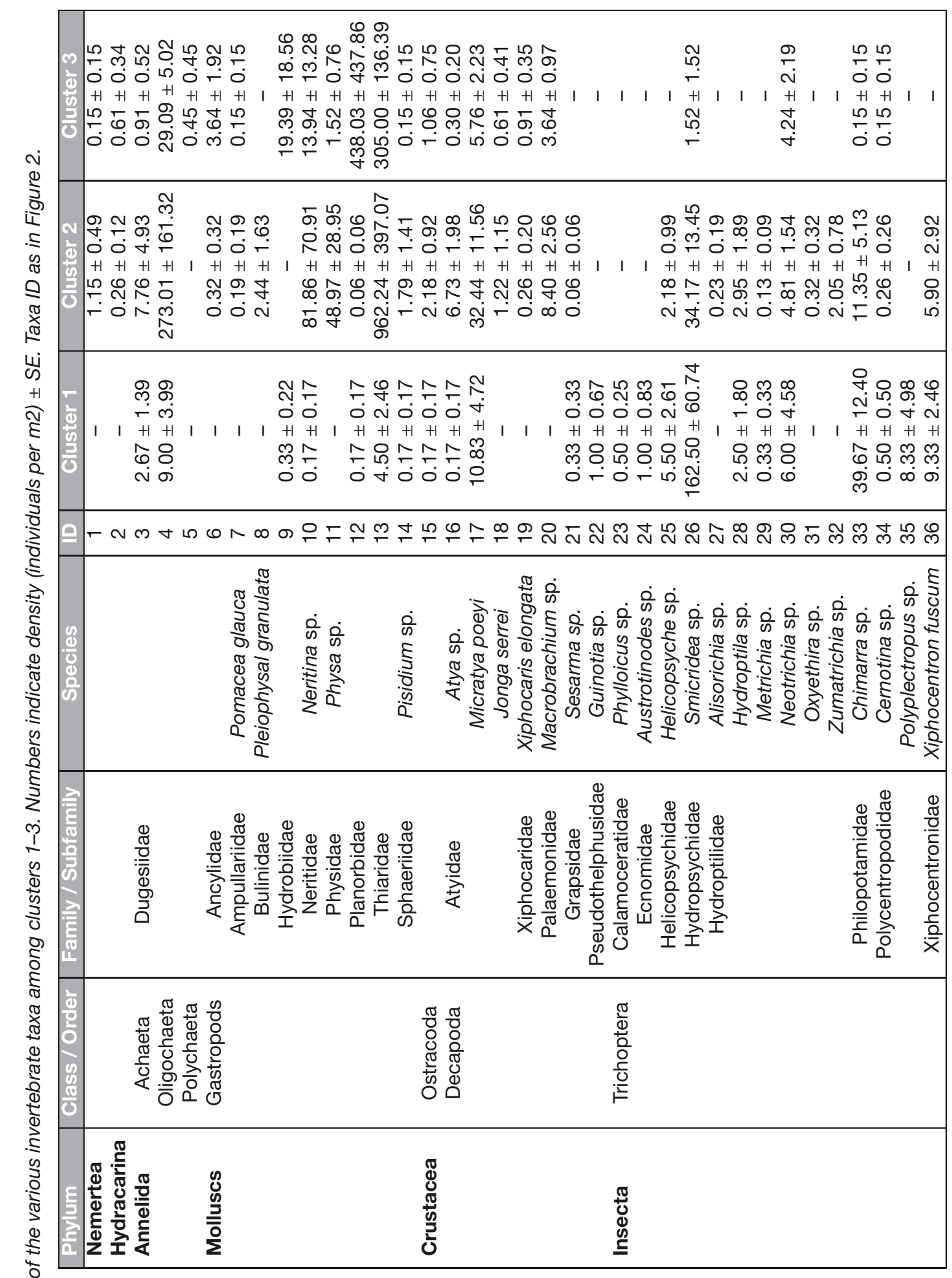




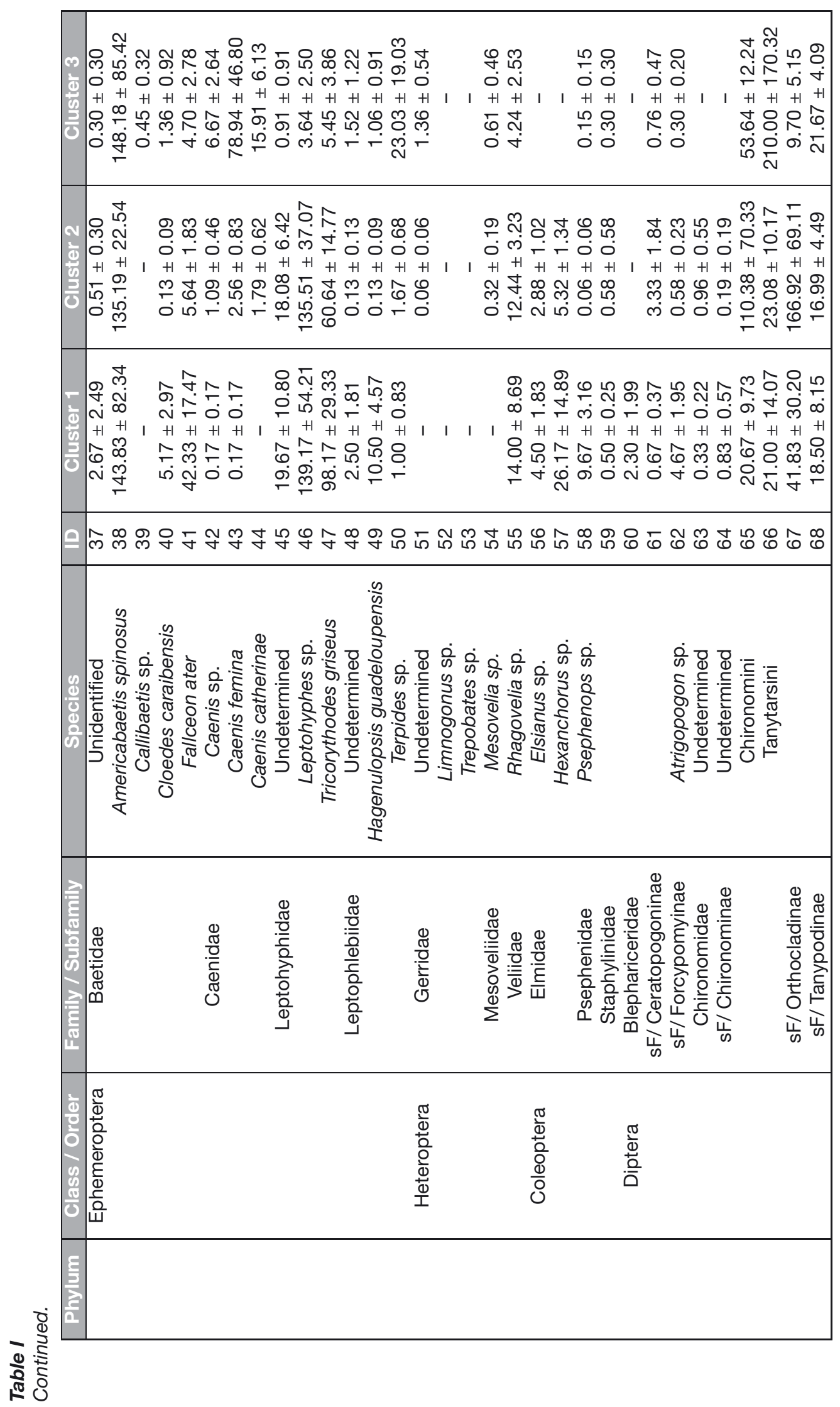




\begin{tabular}{|c|c|c|c|c|c|}
\hline \multicolumn{5}{|c|}{ 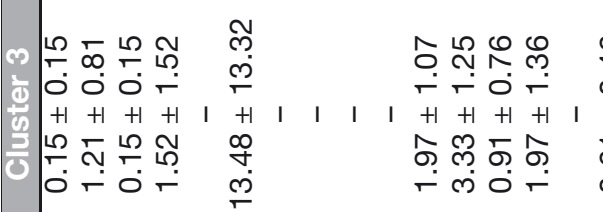 } & $\begin{array}{l}0 \\
+ \\
\vdots \\
+1 \\
+1 \\
\overline{6} \\
\dot{0}\end{array}$ \\
\hline \multicolumn{5}{|c|}{ 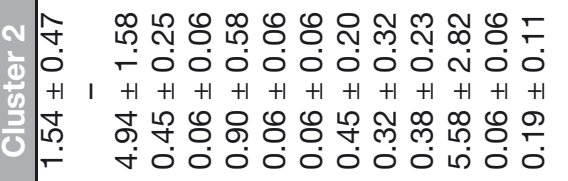 } & 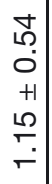 \\
\hline & \multicolumn{5}{|c|}{ 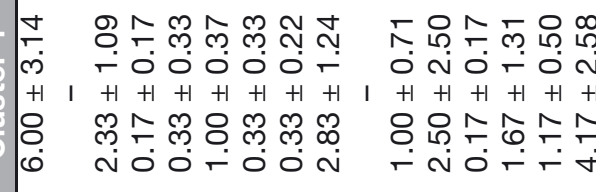 } \\
\hline \multicolumn{6}{|c|}{ 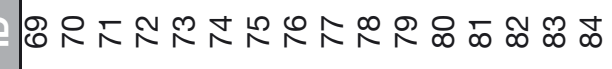 } \\
\hline 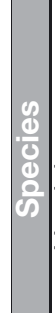 & 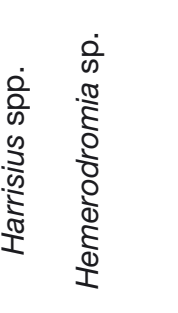 & & 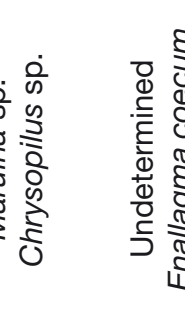 & 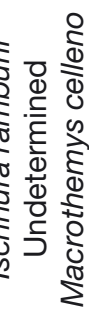 & \\
\hline 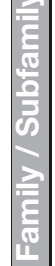 & \multicolumn{4}{|c|}{ 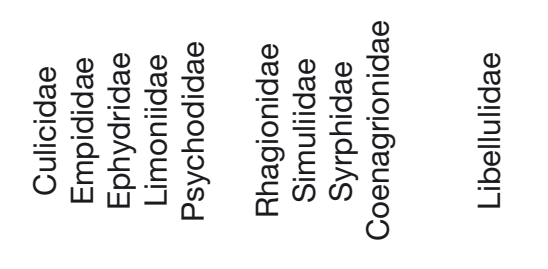 } & 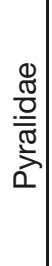 \\
\hline $\begin{array}{l}\frac{1}{5} \\
\frac{0}{2} \\
\frac{8}{2} \\
\frac{2}{10} \\
1\end{array}$ & & & $\begin{array}{l}\frac{\pi}{\pi} \\
\frac{\pi}{0} \\
\frac{0}{0} \\
0\end{array}$ & & $\begin{array}{l}\frac{\pi}{\Phi} \\
\frac{0}{0} \\
\frac{0}{0} \\
\frac{0}{0} \\
د\end{array}$ \\
\hline$\frac{\pi}{2}$ & & & & & \\
\hline
\end{tabular}




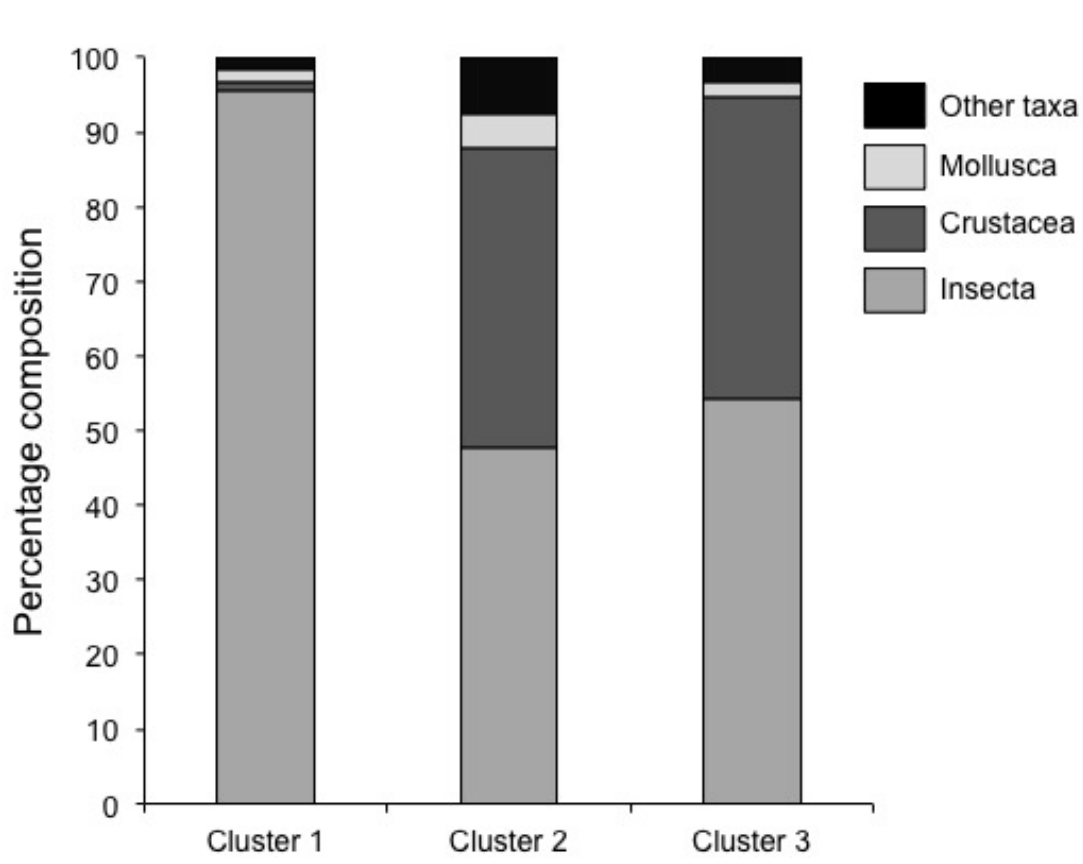

Figure 3

Relative density (\% composition) of higher invertebrate taxa among clusters.

\section{Table II}

Variation partitioning analyses for the entire dataset (all stations) and for each cluster considered separately.

\begin{tabular}{|l|c|c|c|c|}
\hline Variance explained (\%) & All stations & Cluster 1 & Cluster 2 & Cluster 3 \\
\hline Pure geomorphological variation & 28.7 & 56.6 & 18.1 & 43.2 \\
\hline Pure anthropogenic variation & 20 & 31.7 & 17.9 & 41.1 \\
\hline Shared effect & 11.6 & 2.2 & 2.2 & 3.2 \\
\hline Unexplained & 39.7 & 9.5 & 61.8 & 12.8 \\
\hline
\end{tabular}

\section{>MACROINVERTEBRATE DIVERSITY}

Overall, box-plots showed a trend for increasing within-cluster variability in community diversity from cluster 1 to clusters 2 and 3 (Figure 4). No significant difference in community diversity indicators was found between clusters 2 and 3. However, the Shannon and Simpson indices showed a significant decrease from cluster 1 to clusters 2 and 3 (Kruskall-Wallis tests, $P<0.05)$.

\section{DISCUSSION}

Throughout the World, river management efforts rely on explicit spatial distribution schemes (Tate and Heiny, 1995). Specifically, both river typology and reference conditions need to be agreed upon before considering further practical developments such as biological quality indices (van de Bund and Solimini, 2006; Mondy et al., 2012). Numerical patterning is therefore needed to provide theoretical backgrounds, and, more specifically, distribution patterns of freshwater organisms must be derived from environmental conditions with emphasis on the influence of natural conditions and anthropogenic impacts. This study thus provides new quantitative information on the distribution and environmental preferences of freshwater invertebrates in the French Lesser Antilles.

Ordination and cluster analyses are frequently used in the exploratory phase of river typologies (Jongman et al., 1995; Céréghino and Park, 2009). Overall, our results highlight the importance of geomorphology (particle size, river competence and erosive forces in relation 


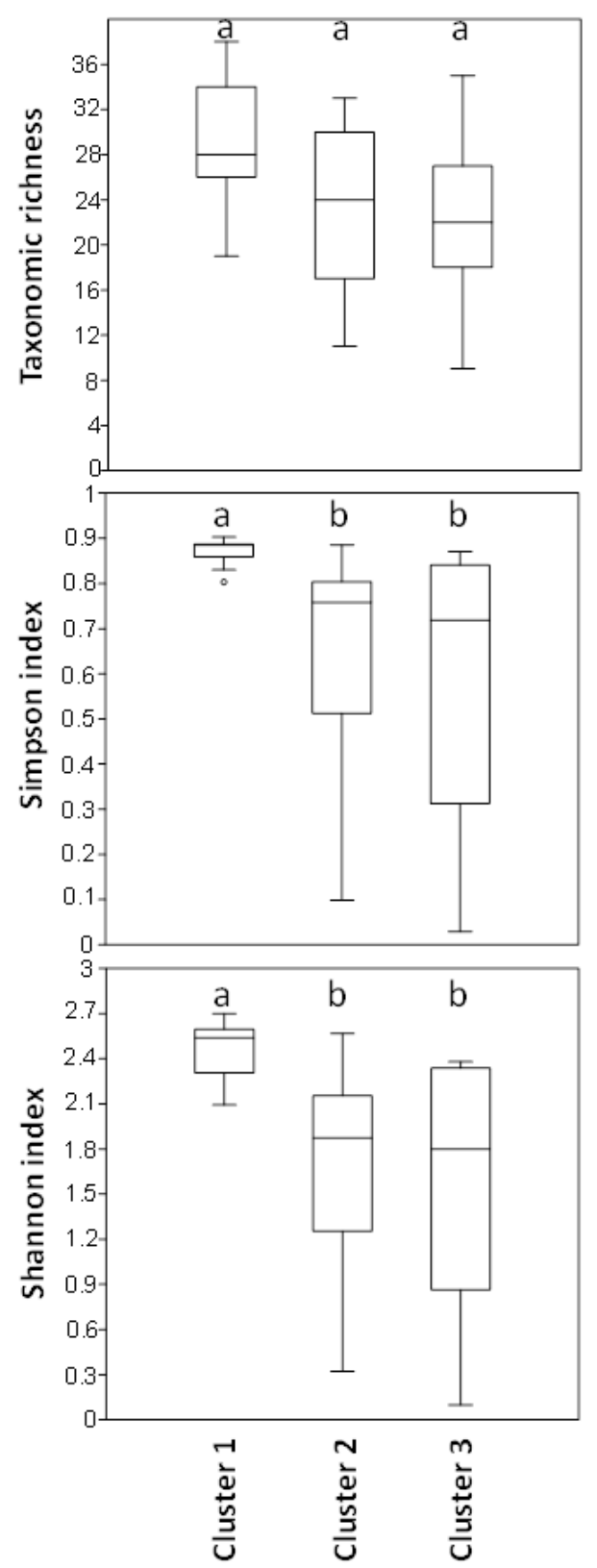

Figure 4

Boxplots of diversity metrics distributions (taxonomic richness, Simpson's evenness, Shannon's Entropy) for the three clusters derived from the CCA and Ward's algorithm, with comparison of pairs of clusters. Significant differences between clusters were tested with Kruskal-Wallis tests; lowercase letters above boxes indicate significant differences at $P<0.05$.

to elevation, conductivity from headwaters to seashore) and land cover (e.g., agricultural lands and related alterations of water chemistry) in delineating ecological sub-regions for the freshwater biota. It should be noted however that the unexplained variation for the entire dataset (all stations) was quite important (39.7\%); therefore, important variables that were not included in our analysis would deserve further investigation. Most stations that formed clusters were geographically adjacent and there was no major spatial discontinuity in invertebrate distribution. Sampling stations were included in our multivariate analysis regardless of a priori consideration of disturbance. Thus, we expected that geographically adjacent stations appearing distant in the ordination space (according to macroinvertebrate communities) would 
represent differences among stations in biological quality. Only four spatial discontinuities were noted among our 51 stations. Station COC (see Figure 1) is close to the northernmost seashore, where it is surrounded by stations typical of cluster 2. However, this station was assigned to cluster 1 in the ordination space. Field observations as well as our data support that $\mathrm{COC}$ is a station of higher biological quality in the area, and could thus form a reference (34 taxa while the maximum local richness is 38 taxa). Conversely, station CAM which is located below vegetable cultivations occurs in a mountainous area typical of cluster 1 , but was assigned to cluster 2. Stations FLS and MOM (Fort-de-France capital city) were expected to belong to cluster 2 based on their geographic location, but were assigned to cluster 3 . These three stations being subjected to important anthropogenic pressure, their distribution in the ordination space was certainly due to the impoverishment of their invertebrate fauna and/or to shifts in species composition from species known as pollution sensitive (e.g., many Trichoptera and Ephemeroptera) to pollution resistant species (e.g., most Mollusca).

The proportion of pure variation explained by geomorphological variables was higher than that explained by anthropogenic variables, however, within a given sub-region (cluster), anthropogenic disturbance affected macroinvertebrate diversity (Shannon and Simpson indices) through physical-chemical alterations of freshwaters (ammonium, suspended solids). It should be noted that the downstream areas (clusters 2 and 3) concentrate most human activities in general, so that here, the relative influences of natural conditions and anthropogenic impacts remain difficult to tease out (see Table II). More specifically, reference stations obviously lack in cluster 3 . Conversely, is likely that cluster 1 was mostly generated through geomorphological drivers. In the north of the island, mountain streams along the volcano slopes represent dynamic environments which are physically heterogeneous (higher river competence generated through the combination of slope with other variables such as water depth and current velocity, higher substrate heterogeneity), thus promoting a high diversity of benthic invertebrates. For example, Diptera Blephariceridae (net-winged midges), which are typical of torrential streams, were only found at stations from cluster 1 . The caddisfly Smicridea sp. (Trichoptera Hydropsychidae), a common taxa in our dataset, showed high to moderate densities in clusters 1 and 2, but was absent in plain rivers from cluster 3 .

Although some taxa were specific of a given cluster, such invertebrates usually occurred in very low densities ( $<1$ individual per $\mathrm{m}^{2}$ ). In fact, most taxa were common; 24 and 42 taxa out of 84 occurred in two and three clusters, respectively. Despite this general trend for ubiquity, individual stations only contained 9 to 38 taxa. This situation raise concerns as to how to define water quality classes in the later phase of applied research, and how to identify sensitive indicator species when (i) local communities are rather poor (insular context, Smith et al., 2003 ; Hughes, 2005 ; Gonçalves et al., 2008), (ii) mean or median values for structural indices (e.g., community entropy and eveness) do not differ greatly in space. However, although many species were widespread, the quantitative structure of invertebrate communities varied markedly among clusters (see results). We thus suggest that future developments should consider quantitative approaches to invertebrate communities, because qualitative metrics related to the loss or a gain of species are not expected to evaluate disturbance efficiently within a given sub-region (cluster).

Insular freshwater invertebrate assemblages are distinct from their continental counterparts in that there are shaped by more complex biogeographical, historical and geomorphological factors (Boulton et al., 2008). Caribbean islands in particular have naturally depauperate species pools that contain endemic species of conservation value (Bass, 2003). At the same time, they harbor spatially-concentrated human populations with important demands for freshwater resource. Despite the small surface area of an island such as Martinique, invertebrate communities show a clear spatial turnover in composition and biological traits (e.g., insects in cluster 1, crustaceans and molluscs in cluster 2) in relation to local natural conditions. If the sensitivity of the biota to disturbance in a given area must be assessed in terms of similarity to an undisturbed state, this study shows that confounding effects of natural and anthropogenic factors (e.g., lack of reference stations in southern Martinique) may limit our ability to estimate deviation from expected patterns when considering the compositional 
structure of communities. Hence, metrics that aggregate taxa into fewer categories than the species list do (percentage composition of upper taxa or a combination of those, trophic or habit measures, Barbour et al. 2009), could be more efficient at predicting a priori responses of communities to environmental conditions, especially if these metrics reflect adaptations to river environments along the downstream gradient and/or along gradients of surrounding landscapes (e.g., Functional Feeding Groups, see Compin and Céréghino (2007)). In these conditions, we would expect reference stations to be less geography-dependent, e.g., estuarine or plain stations of high biological quality could serve as a reference throughout Martinique. Subsequently, a combination of metrics able to detect a wide range of anthropogenic pressures should be selected to set up multimetric indices, as required within the WFD (Hering et al., 2006; Lücke and Johnson, 2009).

\section{ACKNOWLEDGEMENTS}

This study was funded by the French Direction de l'Environnement, de l'Aménagement et du Logement de Martinique (Ministère de l'Ecologie, du Développement Durable, des Transports et du Logement/ DEAL Martinique), the Office de I'Eau Martinique and the Office National de l'Eau et des Milieux Aquatiques (ONEMA). CB is supported by an ANRT-CIFRE grant No. 460/2010; HTP is supported by an ANRT-CIFRE grant No. 912/2010. Two anonymous reviewers provided helpful comments on an earlier version of this paper.

\section{REFERENCES}

AFNOR, 2009. Qualité de l'eau. Prélèvement des macro-invertébrés aquatiques en rivières peu profondes. XP T 90-333. Afnor, 1-15.

Anonymous, 2003. Rivers and Lakes - Typology, Reference Conditions and Classification Systems. Common Implementation Strategy for the Water Framework Directive Guidance. Document No. 10.

ASCONIT, 2012. Mise au point d'un indice de bio-indication de la qualité de l'eau à partir des macroinvertébrés benthiques. Annual Report year 2011. Direction Régionale de l'Environnement et Office de l'Eau Guadeloupe, 1-95.

Bailey R., Norris R. and Reynoldson T., 2003. Bioassessment of freshwater ecosystems using the reference condition approach. Kluwer Academic Publishers, New York, USA.

Barbour M.T., Gerritsen J., Snyder B. and Stribling J.B., 2009. Biological Data Analysis. In: A Rapid Bioassessment Protocols for Use in Streams and Wadeable Rivers: Periphyton, Benthic Macroinvertebrates, and Fish. Second Edition. Rep. EPA/841-B-99-002, US EPA, Off. Water, Washington, DC.

Bass D., 2003. A comparison of freshwater macroinvertebrate communities on small Caribbean islands. BioScience, 53, 1094-1100.

Boulton A.J., Boyero L., Covich A.P., Dobson M., Lake S. and Pearson R.G., 2008. Are tropical streams ecologically different from temperate streams? In: Dudgeon D. (ed.), Tropical Stream Ecology, Academic Press, San Diego, 257-284.

Céréghino R. and Park Y.S., 2009. Review of the self-organizing map (SOM) approach in water resources: commentary. Environ. Modell. Softw., 24, 945-947.

Chaves M.L., Costa J.L., Chainho P., Costa M.J. and Prat N., 2011. Are Water Framework Directive stream types biologically relevant? The case of the Mondego river, Portugal. Ann. Limnol. Int. J. Lim., 47, 119-131.

Colwell R.K., Mao C.X. and Chang J., 2004. Interpolating, extrapolating, and compared incidence-based species accumulation curves. Ecology, 85, 2717-2727.

Compin A. and Céréghino R., 2007. Spatial patterns of macroinvertebrate functional feeding groups in streams in relation to physical variables and land-cover in Southwestern France. Landscape Ecol., 22, 1215-1225.

Cruiskshank M.M. and Tomlison R.W., 1996. Application of CORINE land cover methodology to the UK. Some issues raised from Northern Ireland. Global Ecol. Biogeogr., 4/5, 235-248. 
Delgado C., Pardo I. and García L., 2010. A multimetric diatom index to assess the ecological status of coastal Galician rivers (NW Spain). Hydrobiologia, 644, 371-384.

ENSAT (Ecole Nationale Supérieure d'Agronomie de Toulouse), 1995. Étude faunistique des rivières martiniquaises. ENSA-Toulouse Technical Report, 1-216.

European Council, 2000. Directive 2000/60/EC of the European Parliament and of the Council of 23 October 2000 establishing a framework for community action in the field of water policy, 1-72.

Gabriels W., Lock K., De Pauw N. and Goethals P.L.M., 2010. Multimetric Macroinvertebrate Index Flanders (MMIF) for biological assessment of rivers and lakes in Flanders (Belgium). Limnologica, 40, 199-207.

Gonçalves V., Raposeiro P. and Costa A.C., 2008. Benthic diatoms and macroinvertebrates in the assessment of the ecological status of Azorean stream. Limnetica, 27, 317-328.

Hering D., Feld C.K., Moog O. and Ofenböck T., 2006. Cook book for the development of a Multimetric Index for biological condition of aquatic ecosystems: experiences from the European AQEM and STAR projects and related initiatives. Hydrobiologia, 566, 311-324.

Huryn A.D. and Wallace J.B., 1987. Local geomorphology as a determinant of macrofaunal production in a mountain stream. Ecology, 68, 1932-1942.

Hughes S.J., 2005. Application of the Water Framework Directive to Macaronesian freshwater systems. Biol. Environ., 105, 185-193.

INSEE (Institut National de la Statistique et des Etudes Economiques), 2009. Populations légales 2009 des Départements d'Outre-Mer (DOM). http://www.insee.fr/fr/ppp/bases-de-donnees/ recensement/populations-legales/france-regions.asp?annee=2009.

Jongman R.H.G., Ter Braak C.J.F. and van Tongerenm O.F.R., 1995. Data analysis in community and landscape ecology. Cambridge University Press, UK.

Kelly F.L., Harrison A.J., Allen M., Connor L. and Rosell R., 2012. Development and application of an ecological classification tool for fish in lakes in Ireland. Ecol. Indic., 18, 608-619.

Lepš J. and Šmilauer P., 2003. Multivariate Analysis of Ecological Data using CANOCO. Cambridge University Press, Cambridge, 1-282.

Lions J., Allier D., Pinson S. and Vittecoq B., 2008. Identification des zones à risque de fond géochimique élevé dans les cours d'eau et les eaux souterraines en Martinique. Technical Report BRGM RP56748-FR, 124 p.

Lücke J.D. and Johnson J., 2009. Detection of ecological change in stream macroinvertebrate assemblages using single metric, multimetric or multivariate approaches. Ecol. Indic., 9, 659-669.

Mondy C.P., Villeneuve B., Archaimbault V. and Usseglio-Polatera P., 2012. A new macroinvertebratebased multimetric index (I2M2) to evaluate ecological quality of French wadeable streams fulfilling the WFD demands: A taxonomical and trait approach. Ecol. Indic., 18, 452-467.

Sandin L. and Johnson R.K., 2000. Ecoregions and benthic macroinvertebrate assemblages of Swedish streams. J. N. Am. Benthol. Soc., 19, 462-474.

Smith G.C., Covich A.P. and Brasher A.M.D., 2003. An ecological perspective on the biodiversity of tropical island streams. BioScience, 53, 1048-1051.

Stark B.P., 2000. Notes on the Anacroneuria (Plecoptera: Perlidae) of Guyana with the description of a new species. Aquat. Insect, 22, 305-310.

Starmühlner F., 1977. Contribution to the knowledge of the freshwater fauna of La Reunion (Mascarene). Cah ORSTOM, Ser. Hydrobiol., 11, 239-250.

Tate C.M. and Heiny J.S., 1995. The ordination of benthic invertebrate communities in the South Platte River Basin in relation to environmental factors. Fresh. Biol., 33, 439-454.

Ter Braak C.J. and Smilauer F.P., 1998. Reference manual and user's guide to Canoco for Windows: software for canonical community ordination (version 4), Ithaca, NY, USA.

van de Bund W. and Solimini A., 2006. Ecological Quality Ratios for ecological quality assessment in inland and marine waters. EU project REBECCA Deliverable 10, 1-22.

Wallin M., Wiederholm T. and Johnson R.K., 2003. Guidance on establishing reference conditions and ecological status class boundaries for inland surface waters. Final Report to the European Commission from CIS Working Group 2.3 - REFCOND.

Wu D. and Legg D., 2007. Structures of benthic insect communities in two southeastern Wyoming (USA) streams: similarities and differences among spatial units at different local scales. Hydrobiologia, 579, 279-289. 